\title{
The Initial Training of Librarians and Curators in France: A National Mission
}

https://doi.org/10.1515/bfp-2020-0001

\begin{abstract}
France is probably the only European country to have today a national school for training of library and information professionals: Enssib, National Library and Information Science School. An atypical situation, as some countries decided to close their schools of librarianship and entrust the training of their professionals to universities only. How does Enssib train its library executives? The article first describes the recruitment, training and exercise framework for French library and information professionals. Then it focuses on the vast renovation project that Enssib has been launching for four years in order to adapt its training processes to the needs and expectations of the professional communities.
\end{abstract}

Keywords: Enssib; French National Library and Information Science School; librarians; curators; librarian skills; training processes

Die Anfangsausbildung von Bibliothekaren und Kuratoren in Frankreich: Eine nationale Mission

Zusammenfassung: Frankreich ist wahrscheinlich das einzige europäische Land, das heute eine nationale Schule für die Ausbildung von Bibliotheks- und Informationsfachleuten unterhält: die Enssib, die „National Library and Information Science School“. Eine atypische Situation, da einige Länder heute entscheiden, ihre Bibliothekschulen zu schließen und die Ausbildung ihrer Fachkräfte nur den Universitäten zu übertragen. Wie schult Enssib die Führungskräfte der Bibliothek? Der Artikel beschreibt zunächst den atypischen Rahmen für die Anwerbung, Schulung und Ausübung von Kenntnissen für französische Bibliothekare und Informationsfachleute. Anschließend steht das umfassende Renovierungsprojekt im Mittelpunkt, das Enssib seit vier Jahren durchführt, um seine Schulungsprozesse an die Bedürfnisse und Erwartungen der Berufsgruppen anzupassen.

Schlüsselwörter: Enssib, French National Library and Information Science School; Bibliothekare, Kuratoren; Bibliothekarskompetenzen; Trainingsprozess

*Kontaktperson: Nathalie Marcerou-Ramel, nathalie.marcerou-ramel@enssib.fr
For Herr Dietrich Walther, Stadtbücherei Frankfurt, 1992

France is probably the only European country to have today a national school for training of library and information professionals: Enssib, National Library and Information Science School. An atypical situation, as some countries decided to close their schools of librarianship and entrust the training of their professionals to universities only. The presentation to foreign interlocutors of the French system of recruiting and training library executives has the effect of immediately raising certain astonishment. We will first try to "set the scene" which, rightly so, surprise our counterparts. Then we will focus on the Enssib and the vast project it undertook in 2016 to reform its curricula, including those for librarians and curators. We will try to convince our readers that this particular positioning of the school can also be a force to ensure the development of the skills of our professionals.

\section{An atypical recruitment and exercise framework: back to some French specificities}

French librarians (bibliothécaires), curators (conservateurs) and general curators (conservateurs généraux) are civil servants. They can be part of several public services: the State civil service, the territorial or local public service and that, specific to this community, of the City of Paris. They thus belong to a sector, a status, a body, a grade, which are associated with a career that may not seem favourable to the mobility and adaptability required for modern library jobs. It is possible for institutions to employ a contractor in a civil servant position, but this situation is usually temporary.

Library executives are recruited through competitions, a French specificity, which make them become trainee civil servants. There are several ways of access: the state curators are recruited either by means of an external competition, accessible to the holders of a university diploma of level at least equal to the bachelor; through an "internal" contest open to people having already several years of experience working in the public service; through a com- 
petition reserved for students of the Ecole nationale des chartes $^{1}$ or, more recently, through a competition reserved for the holders of a Ph.D. Due to a limited number of positions (between 20 and 30 per year), external and internal competitions are extremely selective, more than the socalled difficult ones of the National School of Administration (ENA) which trains high-level executives for the public service. It should also be noted that these competitions are run at the national level by the Directorate-General of $\mathrm{Hu}$ man Resources of the Ministry of Education and Higher Education, ${ }^{2}$ and specifically for the state civil service, by the General Inspectorate of Libraries. ${ }^{3}$

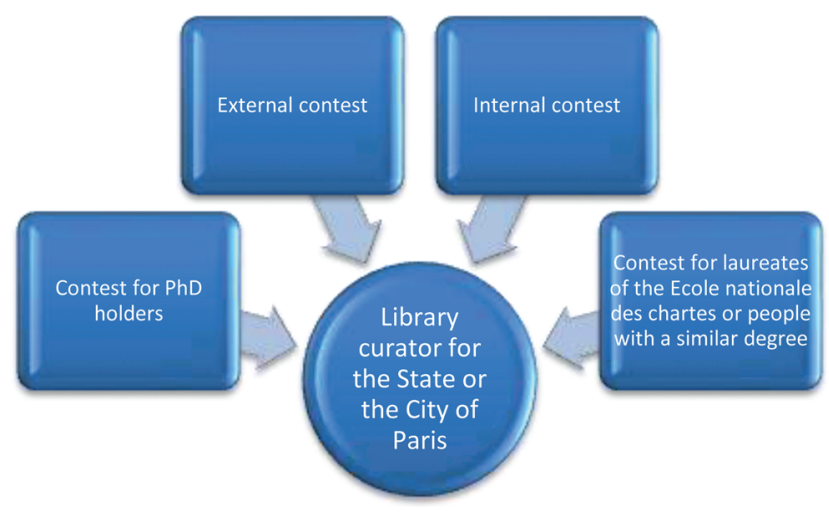

Fig. 1: Ways of access to the Curator profession through a national contest, for the State and the City of Paris

After successful completion of the competition, the trainee civil servants follow, for most of them, ${ }^{4}$ a training of a variable duration (from 6 to 18 months), during which they receive a salary. This training, however high-level, either does not give them a diploma but a professional certification (state librarians) or a certificate of aptitude (territorial curators), either gives them a diploma, that of state library curator (Diplôme de conservateur des bibliothèques, DCB). Certifications and diploma are not registered in the Bologna

1 Founded in 1821, the Ecole nationale des Chartes in Paris among others delivers a diploma entiteld "archivist - paleographer", to people who will then become curators of library, archival, museum or architectural heritage.

2 The Directorate General of Human Resources is responsible for the management of the recruitment and careers of the staff of the Ministries in charge of Education, Higher Education and Research.

3 The General Inspectorate of Libraries (Inspection générale des bibliothèques, IGB) is a control and advisory service under the direct authority of the Minister of Higher Education, Research and Innovation, placed at the disposal of the Minister of Culture for the libraries under its field of competence.

4 The training for librarians recruted for local communities lasts only a few days. university scheme and do not grant ECTS credits. Although, in recent years, many laureates are, at the time of their success in the competition, holders of a doctorate, this diploma is not required to practice as a curator, or even director, in a French library.

After training, state librarians and curators work in institutions under the Ministry of Higher Education, Research and Innovation (universities, other institutions of higher education and research) or the Ministry of Culture (Bibliothèque nationale de France, Bibliothèque publique d'information or in communities with a classified municipal library ${ }^{5}$ ). The librarians and curators recruited by the City of Paris are assigned to the libraries of the network of this community, which includes 57 loan libraries and 15 heritage libraries. The territorial managers are, for their part, included on a list of aptitude which allows them to be recruited by local authorities to practice in their municipal or departmental libraries. However, if no recruitment is made after the forth year of entry on this list, the winner loses the benefit of the competition.

Librarians, curators, are there any differences? Let's go back to the regulatory to the regulatory decrees which organize these bodies. The decree on the special status of the administrative bodies of curator and general curator of libraries ${ }^{6}$ indicates that they "constitute the scientific staff of the libraries" and "are intended to exercise the functions of management and supervision of libraries of the State and its public institutions". ${ }^{7}$ The decree establishing the special status of the librarians' administrative body defines their missions as follows: "librarians participate in the constitution, organization, enrichment, evaluation, exploitation and public communication of collections of any kind of libraries. They also contribute to the facilitation and training tasks in the institutions where they are posted and may be called upon to perform supervisory tasks. They perform their functions in the technical services of libraries under the Ministry of Higher Education or other ministerial departments". ${ }^{8}$ Since the re-creation of its body, in 1992, however, the small number of librarians has struggled to

5 There are 54 classified municipal libraries (Bibliothèques municipales classées, BMC), designated because of the rich heritage collections that they preserve. This system allows the employment of a state curator (paid by the State) at the municipal library to ensure the preservation of these collections of national significance, often resulting from confiscations during the French Revolution.

6 The promotion into the administrative group of general curators is available to curators being in the "curator in chief" level.

7 Décret nº92-26 du 9 janvier 1992, article 1, https://www.legifrance. gouv.fr/affichTexte.do?cidTexte=JORFTEXT000000721523.

8 Décret n92-29 du 9 janvier 1992, article 2, https://www.legifrance. gouv.fr/affichTexte.do?cidTexte=JORFTEXT000000539406. 
Fig. 2: The library profession in France: categories and statuses

\begin{tabular}{|c|c|c|c|c|}
\hline \multirow[b]{2}{*}{ Category } & \multicolumn{2}{|c|}{ State civil service } & \multicolumn{2}{|c|}{ Local civil service } \\
\hline & Status & Degree & Employment framework & Degree \\
\hline \multirow{3}{*}{ C } & \multirow{3}{*}{$\begin{array}{l}\text { Corps des magasiniers des } \\
\text { bibliothèques }\end{array}$} & Magasinier des bibliothèques & \multirow{2}{*}{$\begin{array}{l}\text { Cadre d'emplois des } \\
\text { adjoints territoriaux du } \\
\text { patrimoine }\end{array}$} & Adjoint du patrimoine \\
\hline & & $\begin{array}{l}\text { Magasinier principal de deuxième } \\
\text { classe }\end{array}$ & & $\begin{array}{l}\text { Adjoint du patrimoine principal de } \\
\text { deuxième classe }\end{array}$ \\
\hline & & $\begin{array}{l}\text { Magasinier principal de première } \\
\text { classe }\end{array}$ & $\begin{array}{l}\text { Adjoint du patrimoine } \\
\text { principal de première } \\
\text { classe }\end{array}$ & \\
\hline \multirow{3}{*}{ B } & \multirow[t]{3}{*}{$\begin{array}{l}\text { Corps des bibliothécaires } \\
\text { assistants spécialisés }\end{array}$} & $\begin{array}{l}\text { Bibliothécaire assistant spécialisé } \\
\text { de classe normale }\end{array}$ & \multirow{3}{*}{$\begin{array}{l}\text { Cadre d'emplois des } \\
\text { assistants territoriaux de } \\
\text { conservation du patrimoine } \\
\text { et des bibliothèques }\end{array}$} & Assistant de conservation \\
\hline & & $\begin{array}{l}\text { Bibliothécaire assistant spécialisé } \\
\text { de classe supérieure }\end{array}$ & & $\begin{array}{l}\text { Assistant de conservation principal } \\
\text { de deuxième classe }\end{array}$ \\
\hline & & $\begin{array}{l}\text { Bibliothécaire assistant spécialisé } \\
\text { de classe exceptionnelle }\end{array}$ & & $\begin{array}{l}\text { Assistant de conservation principal } \\
\text { de première classe }\end{array}$ \\
\hline \multirow{2}{*}{ A } & \multirow[t]{2}{*}{ Corps des bibliothécaires } & Bibliothécaire d'Etat & \multirow{2}{*}{$\begin{array}{l}\text { Cadre d'emplois des } \\
\text { bibliothécaires territoriaux }\end{array}$} & Bibliothécaire \\
\hline & & Bibliothécaire hors classe & & Bibliothécaire principal \\
\hline \multirow[b]{3}{*}{ A+ } & \multirow{2}{*}{$\begin{array}{l}\text { Corps des conservateurs } \\
\text { des bibliothèques }\end{array}$} & Conservateur d'Etat & \multirow{2}{*}{$\begin{array}{l}\text { Cadre d'emplois des } \\
\text { conservateurs territoriaux }\end{array}$} & Conservateur \\
\hline & & Conservateur en chef & & Conservateur en chef \\
\hline & $\begin{array}{l}\text { Corps des conservateurs } \\
\text { généraux des } \\
\text { bibliothèques (only } \\
\text { through an internal } \\
\text { promotion) }\end{array}$ & Conservateur général & & \\
\hline
\end{tabular}

find its place in state institutions, while territorial librarians are increasingly gaining access to library management.

\subsection{Training of library executives}

The training of library managers has been organized at the national level since 1963, when the National School of Librarians (ENSB) was created. ${ }^{9}$ The school was then installed in the premises of the National Library, at 2, rue Louvois, in Paris. In 1992, this school only responsible for training the library curators saw its status transformed into a public institution of scientific, cultural and professional mission (EPSCP): it then became the National Library and Infomation Science School (Enssib). ${ }^{10}$ In 1999, it merged with the Institute of Librarian Training (IFB) to form the

9 The École nationale supérieure des bibliothécaires was founded by the Decree $n^{\circ} 63-712,12.07 .1963$, with the status of a national public institution with an administrative function.

10 Enssib is a public institution founded by the Decree $n^{\circ} 92-25$, 09.01.1992, https://www.enssib.fr. state librarian administrative body. Until 2015, Enssib provided unique training to both State and territorial curators.

Since 2015, the training of French librarians and curators has been provided by two institutions: Enssib trains the librarians and curators of the public service of the State and those of the City of Paris, while the National Institute of territorial studies (INET), located in Strasbourg, is in charge of the territorial curators. The National Centre for the Territorial Public Service (CNFPT) has indeed chosen to consolidate at INET the training of territorial administrators, engineers and curators, who will be employed by local administrations. This decision was a kind of earthquake for a profession that still wants to believe in mobility between different public administrations and in the existence of a unique "core business", whatever the type of library in which one exercises. This split has already had significant effects on the choices made by the two institutions now responsible for training curators. The extensive managerial training offered by INET allows territorial conservators to meet the requirements of local authorities who wish to see them accompany major territorial changes, manage teams in a logic of increasing restriction of human and financial resources, and finally other services than libraries. Enssib organizes, in turn, the training in three poles, correspond- 
ing to the three major sets of functions that State curators must simultaneously assume: librarians, scientists and managers.

\section{Enssib in 2019: a "grande école" and $a$ university}

\subsection{Enssib, a national school}

Based in Villeurbanne since 1974, associate member of the University of Lyon, Enssib brings together a team of 100 people: administrative staff, librarians and curators, teachers-researchers and associate professors. In 2015, the departure of the territorial curators and a change of management were the opportunity for Enssib to undertake a vast project of reforms of its training portfolio.

Since its change of status in 1992, Enssib has not only trained civil servants in training: it is also accredited to deliver masters degrees. It currently offers four masters degrees, in collaboration with several universities in Lyon and Saint-Etienne, as well as the École Normale Supérieure de Lyon: Library and Information Science, Cultures of the Script and of the Image, Digital Humanities, and Information Communication. It created two postgraduate degrees, including an international degree with Senghor University in Alexandria; these degrees are largely offered in distance learning, a modality in which Enssib invests financial means and professional skills. Lastly, it offers a wide range of lifelong training courses, mainly intended for public sector library and documentation executives: in 2018, it provided 79 traineeships and hosted a thousand trainees.

This broad spectrum of training, organized according to durations (from one day to 24 months) and variable modalities (face-to-face or distance learning, specific actions or included into a professional curriculum, with or without graduation, on catalogue or at request) contributes to federating an important professional community around the school, unique in its field. It is in this community that Enssib mainly finds its pool of trainers, professionals in charge of teaching courses, supervising study dissertations, offering project management, hosting trainees, participating in training juries or development advice. This allows Enssib to offer a real "continuum" of training to professionals who have now embarked on a process of permanent adaptation to the constant changes in their professions.

In the remainder of this article, we will focus our remarks on the training of trainee curators and librarians from the State and the City of Paris, in other words on what are known as "application trainings". But it is quite obvious that these curricula benefit from the wealth of teaching provided by the school to other audiences and on subjects other than those of these specific ones. Even if it is sometimes difficult-let's face it-to make requirements as diverse as the expectations of the trained public, the pedagogical organization of the training provided, the timetable, the speakers, the regulations of schooling, the different graduations... coexist in a well-known but small institution. An example: each year Enssib manages six different cohorts of students with different schedules. A permanent and sometimes very demanding ballet for the department in charge!

Let's go back for a moment to the term "application training": it is a highly professional training, which must combine learning of fundamental knowledge, of specific professional skills and development of personal skills, abilities to supervise, manage projects, adapt to changes. It alternates periods of theoretical training, at Enssib, and practice time on the field for project management or internships in institutions. These periods allow the trainees either to observe the practices of experienced colleagues or to carry out a mission under their direction. Tutoring is becoming more and more important in the transmission of skills; we will come back to this.

\subsection{The training of the curators of the State and of the City of Paris}

The curator students are, during their training, "assigned" to the Enssib as probationary officials: their direct hierarchy is the school's director. During 18 months, they prepare the diploma of "Library curator" and receive a salary. If they fulfil the obligations of this training, the director of Enssib proposes to the Minister in charge of Higher Education to issue the diploma to the students and to establish them as civil servants. A commission then decides on the assignment of new curators to an institution, following a recruitment procedure during which trainees must choose a position from a closed list and be selected by the institution that proposes it.

This group of curatorial trainees, which has an average of 30 pupils in recent years, joins the group of curators registered on the list of aptitude, i.e. beneficiaries of an internal promotion: representing 6 or 7 people every year, they follow the same lessons as trainee curators, but for the first six months only. They do an internship of one month in an institution and participate in an important pedagogical module on project management. They are not evaluated: at 


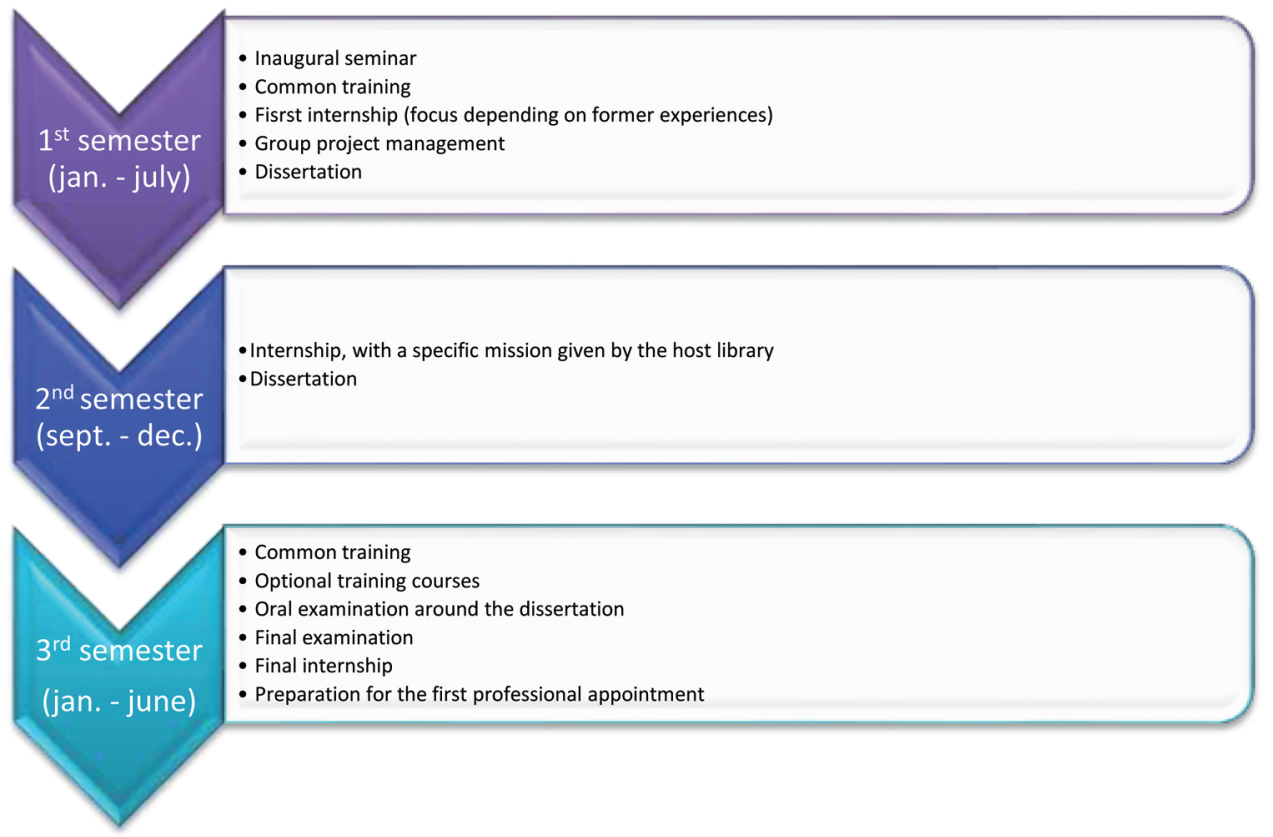

Fig. 1: The training calendar for curator students at ENSSIB

the end of the training, Enssib issues them a certificate of follow-up. As soon as they enter Enssib, they know their future institution and position, the institution most often being the one in which they were already employed in the lower administrative body, that of "librarians".

The results of curator contests, since there are several ways to access this body, are mostly known from the first half of July, but the training of the laureates starts only on January 1 of the following year. This discrepancy - even compared to the academic calendar - reflects the nonregistration of the diploma in the Bologna scheme that we have already highlighted.

Enssib has to deal with two other constraints that it does not have the power to lift. As mentioned above, Enssib does not recruit its students, so it has to prepare and lead to senior management positions people recruited through open competitions which do not, for example, test their technical skills or ability to work in a team. Enssib must also take into account the strong heterogeneity of each cohort. The ages, academic backgrounds, previous work experiences differ greatly. Training must therefore enable both students without previous experience of libraries to acquire a general professional culture and trainees already experienced to question their practices and develop their capacity to hold a senior management position. All within the framework of a curriculum that-probably for a few years more-ranks the laureates at the end according their academic results.

The training of curators is structured around several major areas:
- professional, library, administrative and managerial knowledge,

- three internships, including a fourteen-week one, leading to the writing of an internship report; trainee curators are strongly encouraged to do one of their internships abroad,

- group project management, in which each group works on a real project proposed by a specific library,

- a dissertation on a question of interest to the professional community, which is the subject of a defence. The best dissertations are published in the digital library of Enssib. They represent a non-negligible source of professional publications in French.

\subsection{The training of Librarians of the State and of the City of Paris}

Librarians of the State and of the City of Paris receive a 6months training at Enssib: entering on $1^{\text {st }}$ October, they leave the School on $31^{\text {st }}$ March to join their institution of assignment, which they know before their arrival to Enssib. They do not obtain a diploma, so their training is evaluated but not noted. After six months of training, the director of Enssib prepares a report, sent to the Ministry in charge of Higher Education and the institution of assignment. It is this institution which, after the trainee has spent six months in office, will produce a report on which the Ministry will rely to decide on tenure as a librarian. 
In the curriculum of trainee librarians, we find three of the four poles structuring that of curators:

- Professional, library, administrative and managerial knowledge,

- An internship lasting 4 weeks, leading to the writing of an internship report; it is planned to increase the duration of this internship,

- Group project management, in which each group works on a real project for a specific institution.

\section{A renovated training offer}

\subsection{A revised training engineering}

In 2016, Enssib launched a vast renovation project of its training offer around three main axes:

- contents,

- competency framework,

- educational innovation.

To do this, it has developed training management tools that it did not have until now. Training standards have been developed. In 2017, as part of the complete overhaul of the diploma, which will be discussed below, the first DCB standard was created. It precisely describes the skills expected of a curator in training and articulates them with the different modules that compose the diploma. This approach led Enssib to ask itself questions, and to question its professional community, about the specific job skills the training should aim at: no adapted training repository without a consensus on the expected functions of a senior library officer, but what a complex question in a constantly changing environment!

Each course is provided with a development council (masters, postgraduate degrees of Enssib) or a Council of professionals (DCB, training of librarians and even lifelong training), which in particular allows to evaluate the good professional integration of the trainees, the adequacy between the contents of training, the training models and the real positions and, thus, to improve each curriculum in a continuous way. A DCB professional council was set up in September 2017: a forum for dialogue between the school and its professional community, chaired by the Dean of the General Inspectorate of Libraries. It includes representatives of employers' institutions, major professional associations, recent cohorts and Enssib. Current cohorts of students can be auditioned by the council. A Council of librarian training professionals was installed on the same model in December 2018.
Fig. 4: Common courses for curator students at ENSSIB

\begin{tabular}{l}
\hline Management \\
\hline Deontology \\
\hline Administrative organisation \\
\hline Managing a library institution or department \\
\hline Team management \\
\hline Budget management \\
\hline Project management \\
\hline The manager's toolbox \\
\hline Professional training \\
\hline Libraries and their issues at stakes \\
\hline Documentary policy \\
\hline Services policy \\
\hline Information retrieval \\
\hline Heritage issues in libraries \\
\hline Communication \\
\hline Information literacy \\
\hline Cataloging, bibliography and norms \\
\hline Data and open science \\
\hline Law and libraries \\
\hline Eransversal modules \\
\hline Computer and digital knowledge \\
\hline
\end{tabular}

The policy of evaluating training by learners, either internally or through a national survey is also reinforced as part of this reform. All trainings are subject to a double evaluation by the people who follow it: an oral evaluation, in group, carried out by the person in charge of the training at the end of it; an individual assessment online, at the end of each teaching module. The training evaluation policy is based on another system: as a member of the French Public Service Schools Network (RESP), Enssib is subject to a biennial survey, conducted by an external service provider, which, one year after their exit from Enssib, measures the satisfaction of the librarians and curators former trainees and that of the institutions which employ them. While the results obtained by the school are always difficult to interpret, they provide important trends in the evolution of positions and in the correspondence between the training provided and the expectations of trained staff and libraries. These results are now presented to the Council of professionals, to contribute to further reflection.

Enssib is also engaged in other steps:

- a process of certification and label of trainings modules that the school does not provide itself, but to which it can add value, 
- to be included in national databases as a training provider,

- an involvement in local or national networks that allow to compare and share best practices: we can notably mention that of continuing training structures under the University of Lyon, with which Enssib has signed, in 2017, a quality commitment charter on “Lifelong learning”.

These mechanisms, while not directly benefiting the training of probationary officials, have strengthened the school's pedagogical expertise.

Finally, to carry out its reform, Enssib has made its internal organization evolve: the Department of studies and internships, which includes 34 people (14 teachers-researchers and 20 functional staff), was reorganized into large poles, around training but also transversal ones: a bureau for internships and professional integration, a second for academic procedures and students activities, another one for distance learning. This latter pole, which Enssib wishes to develop in the years to come, is aimed to become a teaching innovation unit. Recent recruitments have encouraged the diversification of skills and approaches within the team, particularly in engineering and educational consulting.

\subsection{Focus on a much-awaited reform: the training of curators}

The arrival of a new director at Enssib in 2015 and a new Head for the department of studies in early 2016 made it possible to start a reform of the DCB, which, at the time of writing, is not quite finished. This reform was necessary and even requested by the professional community. It has been at the heart of the institution's strategy for the 20162020 period.

After an inventory and an analysis of the reforms previously undertaken for this diploma (three since its creation in 1992), a solid benchmarking was conducted with similar public institutions. Seven lines of thought were selected and discussed in several working groups, led by Enssib and the Ministry in charge of Higher Education:

- improving the progressivity of the curriculum,

- redesign the content of the courses,

- revision of the teaching methods,

- strengthening student support,

- revision of the curriculum's calendar,

- review of evaluation procedures,

- registration of the DCB in the Bologna scheme, at the master level.
If several points remain in discussion to date (the revision of the calendar, the evaluation methods, still governed by a decree dating from 1997, and awarding the master's degree to the diploma), the pedagogical evolutions have started in January 2017 and continued in 2018 and 2019. They cover both structural elements (reinforcement and repositioning of internships, with, in particular, an advance of fourteen weeks of professional training from the third to the second semester, project management moved to the first semester, extension of the time allocated to the study and research dissertation) and content (deletion of certain teaching units deemed too close to the prerequisites of the competition, reinforcement of management courses, development of pedagogical partnerships). New courses have been created, especially around digital culture and, in 2019, Open Science.

The evaluation procedures are also refocused on a few strategic tests: a collective project management the professional internship and the internship report, the dissertation, the retention of which was very much discussed. At the time of writing, Enssib is just a few days before the start of the first end-of-training interviews, during which trainee curators of the "DCB 27 - Benoîte Groult" cohort will present their curriculum at a jury made up of Enssib members and professionals. The objectives of this new evaluation scheme are diverse: to evaluate not only knowledge but a rise in skills, to allow curator trainees to defend the path and the choices they made during their training and, finally, to associate more closely the professional communities to evaluate curators who will soon join their teams.

The evolutions of this training are based on enhanced support for trainee curators, a better consideration of their previous career paths, the institution of internal tutoring with specific training for tutors, and a strengthening of induction support, offered during the last weeks of the curriculum. In 2020, a complementary program will be set up, i.e. mentoring: it will allow trainee curators to be accompanied by professionals in the last six months of their curriculum and when they take up their duties. We have already mentioned how important it is to create, as soon as they enter the school, strong links between future curators and their more experienced colleagues. The central position of Enssib, which involves every year nearly 300 external trainers-often librarians or curators in officepromotes the development of this support by peers.

\section{Future developments}

The first results of the survey, conducted one year after the release of the first graduating class (July 2018), will not be 
known until the end of 2019. But, already, the findings and developments have enabled Enssib to establish peaceful relations with the professional community, on the one hand, and with the trainees on the other.

We have described, in the first part of this article, the specificities of the French system for recruiting and training library executives. This system, which may seem very centralized, also has advantages: that of strongly affirming the existence of library-specific professions, for which a high-level training base remains more than ever necessary. As a national school, Enssib has undeniable strengths in delivering these courses.

In recent years, it has reinforced its links with its professional community, with research teams, ${ }^{11}$ particularly within the University of Lyon, as well as its policy of publishing and developing resources in the field of information sciences and libraries. ${ }^{12}$ It has also strengthened its involvement in national (Association of Librarians of France-ABF, Association of directors and senior staff of university libraries and documentation-ADBU, Committee for Open Science-CoSO) and international (LIBER, IFLA) associations.

The school remains vigilant however, well convinced that its task is far from over. It must still complete its thinking on the training of librarians of the State and the City of Paris. Above all, it has to implement a process of permanent evolution for its curricula, whether it be its initial training of civil servants, its masters degrees, or its offer of lifelong learning courses: a necessity if it wants to be able to accompany-to advance?-the technical, organizational and managerial changes in the professions it is building.

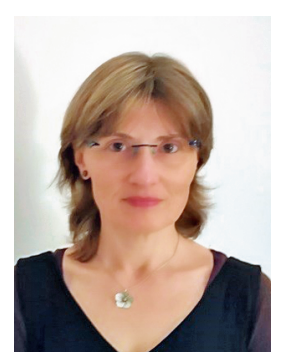

\author{
Nathalie Marcerou-Ramel \\ Director of Enssib \\ 17-21 boulevard du 11 novembre 1918 \\ F-69623 Villeurbanne Cedex \\ France \\ nathalie.marcerou-ramel@enssib.fr
}

11 Enssib is host of a research institute in book history, the Center Gabriel Naudé, et is active in Elico, the large research institute in information and communication sciences in Lyon - Saint-Etienne.

12 Enssib publishes the journal Bulletin des bibliothèques de France (http://bbf.enssib.fr/) and paper and digital collections within the Presses de l'Enssib (https://presses.enssib.fr/). 